\title{
Political Globalization and Foreign Direct Investment Inflows in Turkey
}

\author{
Cem Doğan', Ünal Arslan²
}

\begin{abstract}
This article examines the impact of political globalization on foreign direct investment inflows to Turkey. Existence of foreign missions in a country, membership in international organizations, participation in U.N. Security Council Missions, and International Treaties are all seen as indicators political globalization. Using different econometric techniques, this study aims to find out whether any empirical relationship between political globalization and FDI exists. The analysis in this article covers the period in Turkey between 1970-2012. The results of cointegration analysis provide no an evidence of a long-run or short run any relationship political globalization and FDI.
\end{abstract}

Keywords: Cointegration, FDI, Pesaran bound test, political globalization,

Available Online: $25-06-2016$

This is an open access article under Creative Commons Attribution 4.0 License, 2016.

\subsection{Introduction}

Foreign direct investment is accepted as one of the most important sources of economic development, particularly so after $1980 \mathrm{~s}$. FDI has indeed grown at a phenomenal rate since the early 1980 s. Therefore many researchers in finance and economics try to find the factors that affect the FDI (Haksoon, 2010: 59). According to the UNCTAD report (1998), for example, the determinants of FDI could be classified into 3 main categories. These are politic factors, business facilitation and economic factors.

The basic aim of this article is to demostrate the impact of political globalization of Turkey on FDI. It is analyzed with four main sources. According to the our results, ceteris paribus, investors from different

\footnotetext{
${ }^{1}$ Mustafa Kemal University Faculty of Economics and Administration Science, E-mail: cemdogan@mku.edu.tr

${ }_{2}^{2}$ Mustafa Kemal University Faculty of Economics and Administration Science, E-mail: uarslan@mku.edu.tr
} 
countries are likely to invest in Turkey. Thus the relation between political globalization and FDI into Turkey is positive.

The stock of FDI in Turkey was only \$ million in 1971, and up until 1980 the avarage annual inflow of FDI was only \$90 million. As Balasubramanyam (1996) shows, this was far less than other comparable countries, and FDI did not increase significantly for most of the 1980s (Loewendhal and Ertugal, 2000:3).

This article contains six sections. In section two we give Literature Review of FDI and political globalisation. In section three Turkey and Foreign Direct Investment. In section four empirical Analysis that the realtionship between FDI and political globalisation is examined. In the last section we present empirical results and then conclude the results.

\subsection{Literature review}

In recent years hundreds of theoreretical and empirical studies have tried to explain these kind of questions; what drives decisions on where to invest? How do countries, especially developing and under developed countries attact foreign direct investment and which conditions are conveinent for FDI.

The findings are related with these kind of questions presented in the literature that several factors could facilitate or hinder foreign direct investment inflows. So modeling FDI is a complicated task because so many variables are involved (Mohsin and Zurawicki, 2002: 291). However, several studies have analysed the relationship between FDI and many things. Coughlin, Terza and Arromdee (1991) found for $1981-$ 1983 within the United States that states with higher per capita incomes and higher densities of manufacturing activity attracted relatively more foreign direct investment Habib and Zurawicki (2002), in their article analysed the impact of corruption on foreign direct investment. The results showed that although their perceived high corruption China, Brazil, Thailand and Mexico attract large flows of FDI, Belgium, which is smilarly rated on corruption (by Transparency International) attracts substantial FDI.

Brewer (1993), indicated that, the effects on FDI of government policies, morover depend on the relative cross - national changes in policy as well as the cross - national differences in the levels of policies. Busse and Hefeker (2005), using different econometric techniques for a data sample of 83 developing countries and the period 1984 to 2003 , explained that investment conflict, ethnic tensions and democratic accuntability are important determinants of FDI flows.

Kenyon and Margalit (2014), they have analyazed the emprical relationship between treaty signing and FDI inflows. They showed that signing of intenational economic treaties can help boost foreign investment inflow via its direct effect on the opportunities to benefit from expanded commerce.

Kilmek (2015) in his article examined the relationship between quality of instituonal enviroment and FDI inflows. Using cross - sectional and panal data techiniques, he found that quality of instituonal enviroment plays important role in the process of capital abroad in the form of FDI for 125 economies across 7 geographic regions over the period of time 1996-2011. Anghel (2004), argues that countries whose governments are hishing ranked according to various indices tend to do better in attracting foreign direct investment. According to the findings of her research countries with corrupt, less efficent governments tent to be less attractive for foreign investors. Madeni and Nobakth (2014), in their article accounted for the political determinant of foreign direct investment inflows for 31 Upper - Middle Income Countries (UMCs) over the period of 1990 - 2011. The main findings of the emprical analysis are that democracy enhances FDI toward UMCs.

On the Contrary Castro (2014), found that there is no relationship between democracy and FDI. He claimed that Although lagged FDI is statistically significant and positively correlated with FDI inflows, democracy is not statistically signifcant and it has a limited effect on FDI. 
Hakro and Ghumro (2011), in their article analysis the determinants of FDI flows and to quantify relevent policy shocks for Pakistan economy, by using dynamic econometric VAR model. Their analysis showed that the investment enviroment improving factor statistically significant not only in short run but also in long run. Krifa and Matei (2010), explained by applying two panel models : a fixed effect model and a dynamic panel model (the Arellano - Bond GMM estimator) for a data sample of 33 developing countries covering the period $1996-2008$ that reduced levels of political risk, are associated with an increase in FDI inflows and the business operation conditions appear as an important determinant of the FDI.

Büthe and Milner (2008), explained by focusing on a particular type of international institution that international institutions increase the credibility of government commitments and these institutions affect FDI by giving foreign investor access to markets for inputs and outputs

Nuno Carlos Leitao (2012), in his article argued and provided that globalization has positive effect on FDI. Using static and dynamic panel data techiques he showed that market size, globalization, openness trade and urban population are important for the countries selected are members of OECD in between $1990-$ 2008. Caroline Witte et al., (2015) in their article analyazed what drives MNEs to select low income Sub - Sahran Africa countries. They found that poltic conflict has a negative effect on propensity of a MNE to invest a location. Using a unique dataset comprised of grenfield FDI in low income Sub- Sahran they also showed that the coefficent of colony variable is positive and higly significant, indicatng that MNEs from former colonizer are more likely to invest in a location. Coupet and Mayer (2005), based their study on the relationship between FDI and instititional determinants. They found that institutions mater independently of GDP per capita. According to the their empirical results, for a sample 52 countries, public efficiency in broad sense as a major determinant of invard FDI. Brunetti and Woder (1998), by using large number of uncertainty varaibles in a standardized data set, showed that there is negative association between political violance and FDI. Biglaise and De Rounen (2006), they have analyzed the determinants of FDI inflows in Latin America for 14 countries between 1980 and 1996. By using panal data techinique, they found that most economic reforms have limited effect on FDI flows. They also pointed out that international capital liberalization and privatization are unlikely to attract foreign interests and regime type seems to have little impact on foreign investors.

\subsection{Turkey and foreign direct investment}

Although liberalization programme and export oriented strategy of development initiated in the early 1980 s, Turkey was one of the lowest recipents of FDI among the developing countries until 2000s. During the 1980 s cummulative inflows of FDI was about $\$ 0,168$ billion or $0,86 \%$ of gross domestic invertment (Vural and Zortuk, 2011:15). Because of the unstable political scene, Turkey was not able to utilise its economic growth in 1990 s (Demir, 2013). Thus, in terms of international capital with the cumulative FDI/ GNP ratio and the per capita cumulative FDI was well below the avarage (17.3\%) for Turkey (4.4\%). Morover this ratio was $28 \%$ in developing countries (Akgüç and Ucal, 2003: 9).

In Conclusion, although Turkey shifted to free market economy gradually, FDI flows and export volume remained at low levels during the period $1980-2001$ because of the financal crises and political instability (Bayar, 2014: 26). Come to 2000s a key feature of the Turkish economy over the last decade has been the robust economic growth with an average annual rate of 5 percent. This remarkable performance of growth together with prudent fiscal policies and major structural reforms has integrated the Turkish economy into the globalized world, while transforming Turkey into one of the major recipients of FDI in its region. Turkey has become the 13th most attractive FDI destination in the world by $\$ 123$ billion of FDI in the past decade (Dalgıç, at al., 2012: 10).

\subsection{Empirical analysis}

The co-integration relationship between globalization and foreign direct investments in Turkey has been analyzed in the empirical part of this work, using annual data for 1970-2012. Foreign direct investment data has been obtained from UNCTAD . KOF index has been used as political globalization data. It is first 
necessay to perform unit root tests in order to determine whether any relationship exists between FDI and political globalization.

\begin{tabular}{|c|c|c|c|c|}
\hline \multicolumn{5}{|c|}{ Table 1: Unit Root Test Results } \\
\hline Variables & Model & $\begin{array}{r}\text { Mackinnon Critical } \\
\text { Values (5\%) }\end{array}$ & $\begin{array}{l}\text { Augmented Dickey- } \\
\text { Fuller test statistic }\end{array}$ & Results \\
\hline \multirow{4}{*}{ FDI } & 1** & -2.943427 & -7.905179 & $I(0)$ \\
\hline & II *** & -3.520787 & -9.285521 & $I(0)$ \\
\hline & III **** & -1.951000 & -3.987709 & $I(0)$ \\
\hline & IV ***** & & & \\
\hline \multirow{4}{*}{ POLGLB } & l** & -2.933158 & -0.769667 & I (1) \\
\hline & II *** & -3.520787 & -1.966761 & $I(1)$ \\
\hline & III **** & -1.948886 & 1.866934 & $I(1)$ \\
\hline & IV $* * * * *$ & -2.935001 & -7.994112 & I (1) \\
\hline
\end{tabular}

For this purpose, stationarity of variables were done using Augmented Dickey Fuller (ADF) test. Augmented Dickey Fuller (ADF) test contains three different regression equations.

$$
\begin{aligned}
\Delta Y_{t} & =\mu Y_{t-1}+\sum_{i=2}^{p} \beta_{i} \Delta Y_{t-i+1}+u_{t} \\
\Delta Y_{t} & =\alpha_{0}+\mu Y_{t-1}+\sum_{i=2}^{p} \beta_{i} \Delta Y_{t-i+1}+u_{t} \\
\Delta Y_{t} & =\alpha_{0}+\alpha_{2 t}+\mu Y_{t-1}+\sum_{i=2}^{p} \beta_{i} \Delta Y_{t-i+1}+u_{t}
\end{aligned}
$$

$\tau, \tau \mu$ and $\tau$ x statistics are used for the testing of $\mu=0$ (Dickey and Fuller (1981). To test joint hypothesis on the coefficient provide three additional F-statistics that name are $\Omega_{1}, \Omega_{2}$ and $\Omega_{3}$. The null hypothesis $\mu=\alpha_{0}=0$ is tested by equation $\Omega_{1}$ using statistics. $\Omega_{2}$ is tested by taking a time trend in regression, -i.e. by using (4.3) - joint hypothesis $\alpha_{0}=\mu=\alpha_{2}=0$ statistics. Finally $\mu=\alpha_{2}=0$ joint hypothesis is tested using statistics $\Omega_{3}$ (Enders, 1995: 221-222). Within the scope of these regressions, FDI stability and POLGLB variables have been tested and the results were shown in Table 1. According to the results of the unit root tests, it can be said that the FDA data is constant, while POLGLB data contains a unit root and is first-degree cointegrated. Therefore, Peseran, et al., (2001) test has been used to determine the co-integration relationship.

\subsection{Co-integration test}

Once it has been established that FDI series is stationary and, POLGLB series is cointedgrated in the first order, an unconstrained Vector Autoregression (VAR) model has been developed to determine the optimal level of delay to be employed in co-integration. Optimal lag number was determined as 1 using, LR test statistic (Likelihood Ratio), Final Prediction Error (FPE), Akaike Information Criterion (AIC), Schwarz Information Criterion (SC), Hannan-Quinn Information Criterion (HQ).

Through the bounds test developed by Peseran, et al., (2001), cointegration relationship can be investigated regardless of whether the series are $\mathrm{I}(0)$ or $\mathrm{I}(1)$. For this purpose, firstly an Unrestricted Error Correction Model (UECM) was developed. Adopted version of this model for our study is as follows.

$$
\Delta F D I_{t}=\alpha_{0}+\alpha_{1} t+\sum_{i=1}^{p} \alpha_{2 i} \Delta F D I_{t-i}+\sum_{i=0}^{p} \alpha_{3 i} \Delta P O L G L B_{t-i}+\alpha_{4} F D I_{t-1}+\alpha_{5} P O L G L B_{t-1}+u_{t}
$$

$\mathrm{F}$ test is calculated for detecting the presence of the co-integration relationship. The basic hypothesis for the F-testing is, $H_{0}: \alpha_{4}=\alpha_{5}=0$. Calculated $\mathrm{F}$ test statistics is compared against the lower and upper critical values of Peseran, et al., (2001). If the F statistic is smaller than the Peseran, lower critical value than it is concluded that no co-integration relationship exists. If the $F$ statistics is between the lower and upper values, than no-conclusive comment can be made about the existence of a co-integration 
relationship. Finally, if the $\mathrm{F}$ statistic is above the upper value, this indicates the presence of a cointegration relationship.

\begin{tabular}{lccr}
\hline \multicolumn{4}{c}{ Table 2: Unrestricted } \\
\hline$k$ & F-statistics & \multicolumn{3}{c}{ Correction Model } \\
\hline 1 & & Test Critical Values (level 5\%) \\
\hline 1 & 3.095177 & lower limit & Upper Limit \\
\hline
\end{tabular}

Critical values were obtained from table C (iii) in Peseran, et al., (2001:300) wherein . $k$ is the number of independent variables.

Results obtained from the Unrestricted Error Correction model are shown in Table 2. According to these findings, as a result the analysis performed for the period between 1970 and 2012 in Turkey it was concluded that no co-integration relationship exists between Foreign Direct Investment and Political Globalisation.

\subsection{Conclusion}

The term "globalization" came into popular usage in the second half of the 1980 s in connection with the huge surge of foreign direct investment (FDI) by multinational corparations (Gilpin, 2001:7). Meanwhile many indicators shows that FDI's are determined not only by multinational corparations or firms, but also by culture, historical connection, and political regime in which economic operations are embedded. For this reason FDI's are strongly affected by social and political climate.

Because of the foreign direct investment is accepted one of the most important source of economic development many researchers try to find the factors that affect the FDI. The main theoretical determinants of FDI can be summarised as market access, transport costs, size of the host market, factor costs, trade barriers or openness and investment climate. However, empirical analysis for Turkey between the years of 1970-2012 indicate no cointegration relations between political globalisation and FDI.

\section{Reference}

Alıcı, A. and Meltem, Ş. U., (2003). FDI Exports and Output Growth of Turkey : Causalty Analysis. Paper to be Presented at the European Trade Study Group (ETSG) Fifth Annual Conference $11-13$ September 2003 in Madrid

Anghel, B., (2004). Do Institutions Affect Foreign Direct Investment. http://www.webmeets.com/files/papers/SAE/2005/217/paperFDI.pdf (Second Version 2005) (Date accessed; 08.04. 2016).

Bayar, Y., (2014). Effects of Economşc Growth and FDI Inflows on Unemployment in Turkey. Investment Management and Financal Innovations, 11 (2), $20-27$.

Bigliase, G., and Rounen, K. De (2006). Economic Reforms and Inflows of Foreign Direct Investment in Latin America. Latin America Research Review. 41 (1), 51 - 75.

Brewer, T. L., (1993). Government Policies, Market Imperfections, and Foreign Direct Investment. Journol of International Business Studies. 24 (1), 101-120.

Brunetti, A., and Beatrice W., (1998). Investment and Instituonal Uncertainty A Comparative Study of Different Uncertainty Measures. Weltwirtschafliches Archive, 134 (3), $513-533$.

Busse, M., and Hefeker, C., (2005). Political Risk, Institutions and Foreign Direct Investment. HWWA Discussion Papers 315.

Büthe, T., and Helen V. M., (2008). The Politics of Foreign Direct Investment into Developing Countries: Increasing FDI Throught International Trade Agrements. American Journal of Political Science, 52 (4), $741-762$. 
Carlos, L. N., (2012). Foreign Direct Investment and Globalisation. Actual Problems of Economics, (4). Castro, D., (2014). Foreign Direct Investment and Democracy. Honors Projecst in Economics Paper 18.

Cletus C. C., Terza, J. V. and Vachira A., (1991). State Characteristics and the Location of Foreign Direct Investment within the United States. The Review of Economic and Statistics. 73 (4), 675 - 683.

Dalgıç, B., and Fazlıoğlu, B. and Gasiorek, M., (2015). Export Spillovers from Foreign Direct Investment: Evidence from Turkey. Turkish Economic Association Discussion Paper. 2015/8.

Demir, O., (2013). FDI Attractivenness: Turkey and the BRIC Countries. The European Financal Review December (29).

Dickey, A. D., and Wayne A. F., (1981). Likelihood Ratio Statistics for Autoregressive Time Series With Unit Root. Econometrica. 49 (4).

Enders, W.,, (1995). Applied Econometric Time Series, John Willey and Sons inc., U.S.A. Canada,

Gilpin, R., (2001). Global Political Economy: Understanding the International Order. Princten University Press.

Habib, M., and Leon Z., (2002). Corruption and Foreign Direct Investment. Journal of Business Studies. 33 (2), $291-307$.

Hakro, A. N., Ikhtiar A. G., (2011). Determinants of Foreign Direct Investment Flows to Pakistan. The Journal of Developing Areas, 44 (2), 217-242.

Haksoon, K., (2010). Political Stability and Foreign Direct Investment. International Journol of Economics and Finance. 2 (3).

Kenyon, T., and Margalit, Y., (2014). Does Joining International Treaties Attract Foreign Investment? Experimental Firm - Level Evidence http://www.columbia.edu/ ym2297/KenyonMargalit_March_2014.pdf(Date accessed; 18.03.2016).

Kilmek, A., (2015). Institutions and Outward Foreign Direct Investment" International Journal of Management and Economics 46, $101-119$.

Krifa, Hadjila-Scneider and Iuliana M., (2010). Pollitivcal Risk and FDI in Developing Countries ; Evidence from Panel Data" International Journal of Economics and Finance. 2 (5).

Loewendhal, H., and Ebru E.L., (2000). Turkey's Performance in Attracting FDI: Implications of EU Enlargment. Centre for European Policy Studies Working Document No. 157.

Madani, S., and Mahya N., (2014). Political Regimes and FDI flows : Empirical Evidence from Upper Middle Income Countries. Science and Education Publishing Journal of Finance and Economics. 75 - 82.

Mohsin H., and Leon Z., (2002). Corruption and Foreign Direct Investment. Journal of Business Studies. $33(2), 291-307$.

Pesaran, M.H., Shin, Y., Smith, R.J. (2001). Bounds Testing Approaches to the Analysis of Level Relationships. Journal of Applied Econometrics, 16, 289- 326.

Quere, B. A., Coupet, M. and Mayer, T. (2005). Instituonal Determinants of Foreign Direct Investment. CEPII, Working Paper No 2005-05.

UNCTAD, (1998). World Investment Report Trends and Determinants. United Nations Conference on Trade and Development.

Vural, I. Y., and Mahmut Z., (2011). FDI as a Determining Factor in Turkey's Export Performance. Euroasian Journal of Business and Economics. 4 (7), $13-23$.

Witte, C., Martijn B., Enrico P., (2015). The Effect of Historical Connections on FDI in Conflict Areas in Sub- Saharan Africa http://www.etsg.org/ETSG2015/Papers/458.pdf (Date accessed; 13.03. 2016). 